\title{
GERENCIAMENTO DE COMUNICAÇÃO EM PROJETOS DE TECNOLOGIA DE INFORMAÇÃO
}

\section{Roberta Cristina de Abreu ${ }^{1}$ \\ Ana Cabanas ${ }^{2}$}

Resumo: As áreas humanas possuem domínio e facilidade de integração e disseminação da liderança por isso costumam auxiliar a área de exatas. O gerenciamento em Tecnologia da Informação demonstra certas dificuldades na transição de operacional para gerencial, pelo despreparo no contato com pessoas e clientes. Assim, nesta pesquisa bibliográfica e descritiva com caráter qualitativo aplicou-se o método de abordagem dedutivo e cartesiano com procedimento funcionalista. Nesse estudo o escopo é promover uma visão dinâmica sobre esse profissional e algumas características a serem desenvolvidas para que possa aprimorar os relacionamentos humanos e profissionais. No processo de motivação, a promoção acontece para gratificar o colaborador. Se não houver acompanhamento apropriado nesta mudança de cargos, será considerado desmotivador, afetando diretamente o colaborador em suas responsabilidades e tomadas de decisão.

Palavras-chave: Liderança; Gerenciamento de projetos; Gerenciamento da comunicação; Ferramentas de gestão; Tecnologia da informação.

\footnotetext{
${ }^{1}$ Anhanguera São José, Brasil. E-mail: robertaabreu77@gmail.com.

2 Anhanguera São José, Brasil. E-mail: anakabanass@gmail.com.
} 